\title{
Biodiversidade, política e religião
}

\section{Biodiversity, politics and religion}

Leonardo Boff*

O tipo de civilização inaugurada no século XVI significou com referência à natureza uma verdadeira declaração de guerra. A invenção da ciência experimental e sua tradução por fórmulas matemáticas implicavam uma virulenta intervenção nos ritmos naturais, no intento de conhecer-lhes as leis e transformá-las numa operação tecnológica, a serviço do progresso e do bem estar humano. Tratava-se de domesticar a natureza selvagem e submetê-la aos propósitos do poder.

Este tipo de relação rompeu o elo que unia ser humano e natureza, formando um todo e o sobrepõe à ela, fazendo-o, na linguagem de Descartes, seu "mestre e proprietário". Esse procedimento nos trouxe inegáveis vantagens em todos os campos, especialmente na medicina, nos transportes e nas comodidades cotidianas de nossas vidas. Ao mesmo tempo, cobrou um preço elevado em termos de degradação dos ecossistemas, contaminação dos solos, envenenamento das águas, poluição dos ares, numa palavra, afetou a base físicoquímica que sustenta a vitalidade da Terra.

Esse projeto alcançou nos dias atuais sua culminância com o refinamento cada vez maior das tecnologias que alcançam até as últimas expressões da matéria e o coração da vida. A guerra contra Gaia foi levada com tanta ferocidade que introduziu um desequelíbrio do sistema-Terra, expresso pelo aquecimento global. Este está crescendo a níveis surpreendentes e caso alcançar a 3-4 graus Celsius, pelo final deste século, poderá pôr em risco todas as formas de vida hoje conhecidas, inclusive a espécie humana. Dai a gravidade do atual momento e a urgência de pararmos para avaliar o que fizemos, resgatar o que é possível e traçarmos outra rota que seja amiga da vida e da Terra.

\footnotetext{
* Doutor em Teologia, filósofo, ecologista, membro da Iniciativa da Carta da Terra e um dos seus redatores. País de origem: Brasil.
} 
Em todo este processo a mais afetada foi a biodiversidade. Presume-se que anualmente desaparecem para sempre cerca de cinco mil espécies de organismos vivos. E com eles some para sempre um livro aberto de informações que poderiam ser de fundamental importância para o futuro da vida e da própria evolução, ainda em curso. A manutenção da biodiversidade é de tal importância que dela depende o futuro de nossa existência humana e de grande parte do sistema-vida.

Para se entender, minimamente, a biodiversidade precisa-se incorporar dois conceitos-chaves: a complexidade e a interdependência.

Nada no universo e na Terra é simples. Tudo é complexo, constituindo uma rede de infindáveis fatores, elementos, energias, informações que juntas se articulam e que subjazem ao todo e a cada ser. Grande é a diversidade dos seres vivos tangíveis. Mas estes compõem apenas $5 \%$ de todo o reino da vida; $95 \%$ são feitos de seres invisíveis como as bactérias, os fungos, os virus e outros seres microscópicos. São eles que garantem o equilibrio da Terra, sua vitalidade e integridade. Geralmente, na compreensão comum, não lhes damos importância, pois são apenas "bichinhos" ou "mato" desprezível.

Diz-nos o conhecido biólogo Edward O. Wilson, introdutor da palavra "biodiversidade: "Em um só grama de terra, ou seja, em menos de um punhado de chão, vivem cerca de dez bilhões de bactérias, pertencentes a 6 mil espécies diferentes" (WILSON, 2008, p.26). O organismo humano hospeda bilhões e bilhões de bactérias que ajudam a manter o equilíbrio de nossa vida. Na boca existem duzentos tipos diferentes. No intestino delgado concentram-se cerca de cem milhões por milímetro quadrado e no cólon alcançam a cifra espantosa de cem bilhões por milímetro de quinhentas a mil espécies diferentes.

Uma ervinha de Madagascar, a pervinca rosada, fornece os alcalóides que ajudam a combater a leucemia infantil aguda. Um fungo da Noruega possibilitou o transplante de órgãos e a sua não-rejeição e uma substância da saliva dos sanguessugas se extraiu um solvente que evita a coagulação do sangue nas cirurgias.

As formigas tão minúsculas que somam, mais ou menos, dez quintilhões, pesam sozinhas, o mesmo que todos os 6,5 bilhões de pessoas. Os insetos são tão decisivos para manter a biodiversidade pela polinização que sem eles, provavelmente, a vida se 
extinguiria. E assim em todos os lugares onde há vida, predominam esses microorganismos, fundamentais para a manutenção da vida. Eles formam a complexidade da vida.

O segundo conceito é a interdependência. Todos os seres, mesmo os elementos mais primordiais, estão todos entrelaçados uns com os outros por redes de relações, fazendo que um ajude o outro a se manter na existência e a coevoluir. Nada existe fora das relações e das interdependências. Por isso é grave quando um elo desta rede desaparece. Desestrutura o sistema. Caso este não conseguir se refazer, entra em processo de caos e termina no colapso. É o temor que toma conta dos cientistas face à acelerada extinção de espécies, a ponto de alguns afirmarem que estamos diante da sexta grande extinção em massa, depois daquela que dizimou os dinossauros há 65 milhões de anos.

Diante deste quadro dramático faz-se urgente uma política mundial salvadora. Quer dizer, é necessária uma articulação de forças que vão além da política das nações e dos partidos, que se organiza ao redor de alguns valores e princípios ligados ao respeito, ao cuidado, à cooperação, à responsabilidade e à compaixão. Tais valores poderão inaugurar outro tipo de comportamento necessário face à natureza e a Planeta. Não são poucos os que duvidam que tenhamos o indispensável discernimento e a sabedoria imprescindível para a implementação deste novo paradigma de relação. Mas não temos outra saída. Ou faremos esta transformação ou então não evitaremos uma catástrofe ecológica e humanitária. Possivelmente, em extremo perigo de subsistência, prevaleça o instinto de vida e faremos as mudanças necessárias.

As religiões e os caminhos espirituais desempenham nesta crise paradigmática uma missão especial. Cabe a elas despertar os seres humanos para a reverência face a todos os seres e a todas as formas de vida, pois possuem um valor intrínseco e revelam dimensões do Mistério do mundo e de Deus. O respeito e a reverência impõem limites ao poder avassalador e podem transformá-lo numa potência salvadora dos riscos e das chagas inflingidas à Mãe Terra. A vida constitui o supremo valor criado pelo Senhor do universo e a consciência a culminância de sentido e de reconhecimento daquela Energia amorosa que originou tudo e sustenta a cada um dos seres. Na comunhão com esta suprema Realidade o ser humano encontra as fontes da esperança de que não estamos face a uma tragédia fatal, mas face a uma crise que nos purifica e nos acrisola para um salto novo para frente e para 
cima, rumo a uma forma mais alta da história da própria Terra e do projeto planetário humano.

Confortam-nos as palavras sagradas das Escrituras judaico-cristãs que trazem o propósito do Criador: "Tu amas todos os seres. A todos poupas porque te pertencem, ó soberano amante da vida." (Sb 11,24.26).

\section{Referências}

BÍBLIA SAGRADA. Tradução ecumênica. São Paulo: Paulinas; Loyola, 1995.

WILSON, Edward O. A criação. São Paulo: Companhia das Letras, 2008. 